SECTION 13. Geography. History. Oceanology. Meteorology.

Gulzada Khamitbekovna Bizhanova

Senior lecturer of the Department of History of Kazakhstan and law, basics of economics

Arkalyk State Pedagogical Institute named after I.Altynsarin, Kazakhstan bizhanova81@bk.ru

Laila Sandibekkyzy Baibossyn

Senior lecturer of the Department of History of Kazakhstan and law, basics of economics

Arkalyk State Pedagogical Institute named after I.Altynsarin, Kazakhstan

1.baibossyn@mail.ru

\title{
DEVELOPMENT OF LIBRARY SYSTEM IN CULTURAL CONSTRUCTION OF KAZAKHSTAN (1945-1980)
}

\begin{abstract}
In this article problems of studying the cultural construction of Kazakhstan, development and centralization of a library network in Kazakhstan in post-war years are considered, and also the comparative analysis for premilitary and post-war years are given.

Key words: library system, cultural construction, library network, Kazakhstan.
\end{abstract}

\section{РАЗВИТИЕ БИБЛИОТЕЧНОЙ СИСТЕМЫ В КУЛЬТУРНОМ СТРОИТЕЛЬСТВЕ КАЗАХСТАНА (1945-1980 гГ.)}

Аннотация: $B$ данной статье рассматриваются проблемь изучения культурного строчтельства Казахстана, развития и иентрализации библиотечной сети в Казахстане в послевоенные годы, а такәсе дается сравнительный анализ за предвоенные и послевоенные годы.

Ключевые слова: библиотечная система, культурное строчтельство, библиотечная сеть, Казахстан.

В истории, в деятельности, в поступках каждого человека нет ничего, что не имело бы «культурного аспекта». «Культура никогда, даже в самые революционные моменты не бывает несущественной мелочью» [1, с.80].

Напротив являясь первоисточником нравственности общества, его интеллектуального уровня, она представляет собой одну из тех социальных сил, которые определяют пути и темпы развития этого общества. Культура становится как бы основой в стремлении людей оградить себя от угрозы потери «плодов цивилизации», в чем и заключается смысл изменнений «общественных форм»[2, с.254].

В тех нередких, к сожалению, случаях, когда забывают об этой мере человечности, гуманности общества, неизбежны миллионы жертв, социальные и экологические бедствия, другие негативные последствия. В данной связи показателен опыт проведения культурной революции в СССР. Расчитанная на длительный период и ставившая перед собой целью прежде всего овладение уже созданными культурными богатствами, она на практике была заменена переворотом, направленным на создание «новой» социалистической культуры, оторванной от народных традиций, замененных догмами сталинской идеологии. В результате наше общество, вопреки существующим по сей день иллюзиям, отнюдь не вышло «на небывалые высоты культурного прогресса», а оказалось в состоянии деградации.

В этом отношении очень важно осознать, что, как справедливо отметил 
Д.С.Лихачев, «нам не удастся реформировать экономику, науку, общественную жизнь, если наша культура будет находиться на нынешнем уровне» [3, с.1]. От декларативных заявлений о приоритете развития культуры необходимо перейти к разработке обоснованной программы действий по духовному возрождению общества. Это же, в свою очередь, предполагает изучение культурной ситуации, ее динамики за годы Советской власти, анализ опыта культурного строительства, его уроков. Особую значимость такой анализ имеет для села, культурную отсталость которого некоторые исследователи сегодня не без основания склонны рассматривать не иначе, как «пятую колонну перестройки» [3, с.20]. Именно сельская культура уже с первых лет Советской власти стала объектом особого внимания как со стороны государственных, так и партийных органов, и именно на ее состоянии, как нельзя более отчетливо, отразились все позитивные и негативные тенденции партийно-государственного руководства всей культурной сферой в целом [4, с 5-6].

Перед партией и советским государством стояла сложнейшая задача решения социально - экономических проблем страны. Необходимо было расширять и углублять процесс демократизации общественной жизни, развивать инициативу, творчество трудящихся, осуществить поворот от технократизма к человеку как высшей цели и определяющему фактору перестройки. Требует совершенствования организация свободного времени. Решение этих и других задач невозможно без нового существенного подъема духовной культуры всех советских людей, и в частности, сельского населения. «Духовная культура - не только украшение общества, а сфера его жизнеобеспечения, интеллектуальный и культурный потенциал общества», подчеркивал М.С.Горбачев. Это как бы легирующий материал для его социальной прочности и катализатор для его динамичности [5, с.263].

Возрастание социальной роли духовной культуры в условиях социализма определяет необходимость изучения ее различных аспектов, в том числе и проблемы культурного строительства в ауле и селе Казахстана в 60-е - первую половину 80-х годов [6, с.2-3].

Важное значение для развития библиотечного дела в Казахстане имел изданный в 1920 году первый библиотечный закон - декрет Советского правительства «О централизации библиотечного дела в РСФСР», и определивший принципиальную основу и пути развития библиотечного дела как общегосударственной системы. Несколько позже Главполитпросвет Казахстана разработал специальный документ о создании единой библиотечной сети.

В последующие годы в республике была начата большая работа по организации новых публичных библиотек, определению их видов, разработке положений и руководящих материалов по созданию единой сети, книгоснабжению библиотек и т.д. $[7$, c.49].

Уже к началу 1922 года на территории Казахстана работали 622 библиотеки разных типов, то есть почти в 5 раз больше, чем в 1913 году. Планомерное формирование и укрепление системы библиотек в республике осуществлялось на государственной основе.

В годы первых, предвоенных пятилеток, которые характеризуются стремительным развитием промышленной индустрии и сельского хозяйства, подготовкой национальных кадров происходит интенсивный рост библиотек различных типов. В 1940 г. в Казахстане действовало около 4000 библиотек, в том числе 95 научных и специальных. Начавшаяся Великая Отечественная война 1941-1945 гг. не только прервала развитие этих процессов, но и привела к некоторому сокращению сети библиотек. За послевоенные годы развитие библиотечного дела в Казахстане шло быстрыми темпами [8, с.31].

За 30 лет - с 1945 по 1975 годы число публичных библиотек возросло почти на 
5000. К 80-м годам в республике имеется более 17 тыс. библиотек различных типов массовых, научных, специальных, школьных и других. Особенно значителен рост массовых библиотек. Сеть их по сравнению с дореволюционным периодом увеличилась в 62 раза, книжный фонд в 810 раз. Быстрый рост сети библиотек и их фондов сделали книгу доступной для основной массы населения. Каждый человек имеет возможность пользоваться библиотекой [9, с.271].

Объем работы областных библиотек постоянно возрастает, расширяется сфера их научно - методической, информационно - библиографической, справочной и научно - исследовательской работы.

В республике действуют 227 районных и 5600 сельских библиотек, то есть в каждом сельском совете в среднем имеется по 4-5 сельских библиотек.

Особенностью Казахстана является существование более 10 тысяч мелких, отдаленных на десятки километров от культурных центров населенных пунктов, в которых живут по нескольку чабанских семей. Их обслуживание осуществляется в основном автоклубами, которых в республике 1,5 тыс., примерно по 12-15 машин на животноводческий район. В населенных пунктах, где размещены укрупненные чабанские бригады, создаются передвижные библиотеки от сельских библиотек.

Кроме отечественной документации, ряд научных и областных библиотек, получают патентную документацию из 42 стран мира, в том числе из стран участниц договора о патентной кооперации - США, Великобритании, ФРГ, Японии, Франции, Швейцарии. Важными источниками комплектования фондов библиотек является внутрисоюзный и международный книгообмен. Так, только Государственная библиотека им. Пушкина ведет обмен с 200 библиотеками нашей страны и 55 организациями 27 зарубежных стран.

За последние 10-15 лет в республике проведена значительная работа по совершенствованию организации сети массовых библиотек: уточнены зоны обслуживания каждой библиотеки, свыше 450 профсоюзных и приклубных библиотек объединены с другими или реорганизованы в филиалы, около 250 перемещены из мелких в крупные населенные пункты и микрорайоны.

Важной задачей остается дальнейшее повышение уровня работы библиотек Казахстана, укрепление их связи с жизнью, с практикой коммунистического строительства, активизация работы по привлечения в библиотеки новых читателей.

Решению этих задач во многом способствует, проводимая ныне в республике реорганизация библиотечной сети, ее централизация, которая ведется на основе четкого планирования работы.

Экспериментальная работа по централизации сети государственных массовых библиотек была начата в 1972 году. Созданы опытные базы, расположенные в разных экономических и географических районах, разное количество жителей и сеть библиотек. Созданные опорные централизованные системы в г.Целинограде, г.Кентау, в Джувалинском районе Джамбульской области, Каскеленском районе, детская централизованная система в г. Джамбуле [10, с.2-3].

К 1980г. в республике должно функционировать 262 централизованные системы, что позволить расширить сферу влияния библиотек, улучшить состав книжных фондов и повысить их использование, совершенствовать формы нестационарного обслуживания, шире внедрить в практику массовых библиотек информационно - библиографическое обслуживание читателей, укрепить контакты библиотек разных ведомств и систем между собой и органами информации, расширить деятельность между библиотечного абонемента, усилить организационно-методическое руководство библиотечным делом [11, с.6-7].

Централизация библиотечной сети позволит не увеличивать сеть новых библиотек, а качественно укреплять существующие. Поэтому темпы роста 
библиотечной сети в дальнейшем будут несколько снижены. В 1976-1980 гг. планируется открытие только 700-800 библиотек [12, с.71].

Опыт библиотечного дела в Казахстане свидетельствует о том, что постоянное внимание государства, планирование и осуществление коренных экономических преобразований, направленных на социальное развитие народа и подъем его материально-культурного уровня, развитие многонациональной советской культуры обеспечивают широкое обслуживание трудящихся книгой.

Предстоит дальнейшее укрепление материально-технической базы библиотек, совершенствование научной организации труда в библиотеках, внедрение автоматизации и механизации библиотечных процессов, более эффективное использование внутренних ресурсов библиотечной системы республики.

\section{References:}

1. Струве П.Б. Скореее за дело! // Молодой коммунист. 1990г. №8. Стр.80.

2. Канапин А.К., Яндаров А.Д. Расцвет культуры казахского народа. Алма-Ата, 1977. - 254 стр.

3. Кузин С.Н. Автореферат диссертации на соискание ученой степени кандидат исторических наук. Культурное строительство на селе: опыт, проблемы, уроки партийно - государственного руководства 1976-1985 гг. Ярославль, 1990. Стр.1.

4. Чурбанов В. Культура села: перед восхождением // Советская культура. 1989. 22 июня.5-6 стр.

5. Чубарьян О.С. Проблемы истории библиотечного дела в СССР. М., 1979 - 263 стр.

6. Арнольдов А.И. Социалистическая культура: теория и жизнь. М., 1984 г. 2-3 стр.

7. Абжанов Х.М. Сельская интеллигенция Казахстана в условиях совершенствования социализма. Алма-Ата, 1988г.-с.49.

8. Планирование работы сельской библиотеки. Алма-Ата, 1969г. 31 стр.

9. Серов В.В. Совершенствование системы библиотек в развитом социалистическом обществе. М., 1981г. - 271стр.

10. Кудайбергенов А.Н. Автореферат диссертации на соискание ученой степени доктора исторических наук. Культурное строительство в ауле и селе Казахстана в 1961-1985 гг. Алма-Ата, 1991. Стр.2-3.

11. Садыкова У.К. Развитие библиотечной системы в Казахстане. Москва, 1975 г. Стр.6-7.

12. Актуальные проблемы развития библиотечного дела Казахстана. Алма-Ата, 1987 г. Стр.71. 